\title{
The Making of Canadian Economists - Results of a Survey of Graduate Students
}

\section{HERBERT G. GRUBEL*}

\begin{abstract}
The responses to questions by 155 students revealed the following, most important facts. The students predominantly came from families with high incomes. They have leftist political leanings, though through their training, more have turned right than left.

The students share most strongly the views on fundamental propositions in economics held by U.S. graduate students and less those held by Canadian and U.S. professionals. Students from different Canadian universities hold very similar views on price-theoretic propositions but rather widely differing views on some important issues of macro-economics and income distribution.

The most important finding is that, like their U.S. colleagues, Canadian graduate students believe that for professional success it is more important to learn technical skills rather than about institutions, history and policy. As a result they end up poorly prepared for work on economic policy issues and their research tends to lack real world relevance, even though real world and policy problems attracted them to the graduate programs.
\end{abstract}

\section{Résumé}

Les réponses de 155 étudiants révèlent les faits suivants. Les étudiants viennent en majorité de familles de niveau socioéconomique élevé. Leurs idées de base sur la politique sont de gauche, quoiaque, suite a leur entrainement, la majorité pench vers la droite.

Les étudiants partagent leurs idées sur les théories économiques fondamentales le plus fortement avec les étudiants post-gradués américains et moins avec les professionnels canadiens ou américains. Les étudiants des différentes universités canadiennes ont des opinions très semblables sur la théorie des prix et ses hypothèses, mais ne s'accordent pas en ce que concerne certains sujets importants en macro-économie et la distribution des revenus. 
La fait saillant qui ressort de cette étude est que, come leurs pairs américains, les étudiants post-gradués canadiens croient que pour réussir dans la profession il est plus important d'apprendre certaines techiques plustôt que do connaitre les institutions, l'histoire et la politique économique. En conséquence ils sont mal préparés a travailler sur les questions de politique économique. Leurs travaux de recherche ont peu ou pas de portée sur la réalité courante malgré le fait que c'est cette réalité et les problèmes de politique économique qui les ont attirés vers les programmes post-gradués.

"Departments of economics are graduating a generation of idiots savants, brilliant at esoteric mathematics yet innocent of actual economic life." This quote from Kuttner (1985) was presented by Colander and Klamer (1987) in a review of 212 survey responses by U.S. graduate students in economics. These authors had designed the survey in order to gain insights about the validity of the Kuttner observation and, more generally, the sociological characteristics of graduate students, their views on methodology and the importance and acceptance of certain ideas.

This study reports the results of a similar survey of Canadian graduate students in economics. Many of the questions of the Colander and Klamer study were used in order to shed some light on the similarity of Canadian and US graduate programs. Some of the questions are also the same as those given to professional economists in Europe and the United States, as reported by Frey et al. (1984) and in Canada as reported by Block and Walker (1988). In addition some questions have been included concerning the optimum use of mathematics raised in a survey of academic economists by Grubel and Boland (1986).

The first section discusses briefly the design for the survey and presents a demographic profile of the students who returned completed questionnaires.

\section{Survey Design and Student Profile}

In the Spring of 1987 questionnaires were distributed to professors of economics at 23 Canadian universities; and these recipients were asked to make the survey available to graduate students, to designate a mail-box for their return and to mail the completed surveys to the author. Anonymity of responses was assured since the questionnaire did not contain names. The author's thanks go to those colleagues who by this mechanism generated the return of 158 completed questionnaires. ${ }^{1}$

Data were received from 17 universities. The number of responses in the aggregate represents 24 percent of the graduate students who received the survey. ${ }^{2}$ The response rate from universities in Quebec which have French as 
the language of instruction was limited to four from the University of Laval. This may be due in part to the fact that the questionnaire was in English. For this reason and because of the biases which creep into all survey answers, it is wise to retain a healthy skepticism about the validity of any generalizations for the population as a whole.

\section{Demographics}

The surveys were completed by 128 males and 27 females $^{3}$, with average ages of 27.5 and 29.9 respectively. The foreign born were 42 percent of the number of students who responded. Those with visitors' visas and non-Canadian citizenship represented 35 percent of the total. Among the foreign born, the largest number were from China (10), USA (7), UK (6), Hong Kong (4), India (4), South Africa, Ghana, Greece and Pakistan (3 each), other Asia (7), other Europe (5), Middle East (1), other Africa (5), Latin America (3) and Australia (1). Fifty-eight percent of the students had a long-term relationship and 22 percent had children.

The parental background of the students is summarized in Table 1, showing separate data for Canadian and foreign nationals. Half of the Canadian students have parents with an annual family income between $\$ 30,000$ and $\$ 80,000$ while about half of the parents of foreign students have annual incomes below $\$ 30,000$. However, it is interesting to note that in the income class of $\$ 80,000$ and over Canadians and foreigners are represented by nearly the same percentage of 17 and 15 , respectively.

Table 1 also shows that large proportions of the Canadian students have parents who are either professionals (such as doctors, lawyers, engineers, dentists and managers) or academics and teachers, and have high levels of educational attainment. Perhaps the findings are best summarized by the fact that 30 percent of the fathers are either professionals, academics or teachers and 48 percent have a B.A., professional, M.A. or Ph.D. degree. A separate compilation shows that 7 percent of the students come from families where both the father and mother are professionals, academics or teachers.

Of the Canadian and foreign students, 16 and 26 percent, respectively, graduated from a private high school. Economics was a major or minor for 119 of all of the students during their undergraduate studies. Other majors and minors noted were Natural Sciences and Engineering (11), Business Administration (7), Mathematics (6), Political Science (4) and Psychology (2), as well as one each in Computer Science, Urban Planning, History, Sociology, International Affairs, Statistics and Philosophy. Over one half of all students (53 percent) had full-time work experience before entering graduate school. 
Table 1

Background of Parents

\section{Nationality \\ Canadian Foreign \\ (Percent of All Students in Category)}

A. Annual Family Income ( $\$$ thousand)

$\begin{array}{lll}\text { Less than } 30 & 34 & 48 \\ \text { Between } 30 \text { and } 80 & 49 & 37 \\ \text { More than } 80 & 17 & 15\end{array}$

B. Mother's Occupation

Retired, deceased or not available $\quad 10 \quad 24$

Professional $11 \quad 3$

Academic or teacher $\quad 5 \quad 13$

$\begin{array}{lll}\text { Other } & 74 & 60\end{array}$

C. Father's Occupation

Retired, deceased or not available $\quad 12 \quad 22$

$\begin{array}{lll}\text { Professional } & 23 & 12\end{array}$

Academic or teacher $\quad 7 \quad 13$

$\begin{array}{lll}\text { Other } & 58 & 53\end{array}$

D. Mother's Educational Attainment

$\begin{array}{lrl}\text { High School or less } & 61 & 63 \\ \text { BA or equivalent } & 33 & 27 \\ \text { Professional, MA or PhD } & 6 & 10\end{array}$

E. Father's Educational Attainment

$\begin{array}{lll}\text { High School or less } & 52 & 50 \\ \text { BA or equivalent } & 23 & 24 \\ \text { Professional, MA or PhD } & 25 & 26\end{array}$

\section{Current Educational Interests}

Among the respondents, one-half expected to graduate with an M.A. and onehalf with a $\mathrm{Ph} . \mathrm{D}$., respectively. Fifty-two percent were in their first year, 21 percent in the second, 10 percent each in the third and fourth and 7 percent in the fifth and later years of graduate study. Of those in a Ph.D. program, 39 percent had completed all of their coursework. Fifty-eight percent were working on an MA or Ph.D. thesis. Table 2 shows the fields in which the thesis is written. International Economics dominates by a wide margin. 
Table 2

Fields of M.A. or Ph.D. Thesis

Total Replies: 95

International Economics

Public Finance, Taxation

Money, Banking, Finance

Natural Resource Economics

Economic Development

Micro-Economics

Macro-Economics

Econometrics

Labour Economics

Industrial Organization

Dynamic or Linear Programming

Regional Economics

Law and Economics, Health Economics,

Demography, Game Theory
Number in Field

19

13

12

9

9

6

6

4

4

4

3

2

each 1

In response to the question, "In 15 years from now you hope to be where?", 27 percent answered 'teaching at a major university'; 6 percent 'teaching at a good liberal arts college'; 11 percent 'working at a major research institution'; 15 percent 'doing research in a policy oriented think tank'; 29 percent 'working in the private sector'; and 12 percent 'working in government' 4

\section{Financing}

Before starting graduate work, 55 percent of the students had the assurance of a scholarship, 76 percent of a teaching assistantship. Only 5 percent have taken out a private sector loan and 28 percent receive financial help from parents. For 80 percent of the students scholarships and teaching assistance provide the most important source of finance. For about 20 percent private income from their own work or that of spouses is the most important source of finance.

\section{Influences on Study and Thesis}

The question "How important were the following in your decision to do graduate work in economics?" was answered by students marking the choice 3 : very important, 2: somewhat important or 1: unimportant. A simple summary index of the responses was constructed by calculating the mean of the numerical values given by the students. ${ }^{5}$ The ranking of the answers is determined by the value of the index of importance. 
a. Economics seemed the most relevant field given my intellectual interest 2.40

b. Enjoyed undergraduate classes in economics -2.38

c. Desire to engage in policy formulation -2.31

d.Good grades in economics classes -2.21

e. Advice of undergraduate teachers -1.71

f. Wanted a job in academia and economics seemed the best possibility -1.65

g. Political reasons -1.32

The question "What has been the major factor in your choice of a thesis topic?" produced the following indices of importance, constructed in the manner discussed above.

a. Finding answers to pressing current economic problems -2.30

b. The desire to understand some economic phenomenon -2.12

c. The feasibility of a topic and to get it done quickly -2.03

d. The suggestions of a teacher 1.82

e. The application of some econometric technique -1.67

f. The application of a mathematical technique -1.52

\section{Importance of Learning Vehicles and Sources of Stress}

In response to the statement "The different learning vehicles have been for me: 3: very important; 2: moderately important; and 1: least important", the responses produced the following values and ranking for the summary index:
a. Classroom lectures -2.48
b. Assigned readings -2.38
c. Discussions with other student s- 2.10
d. Unassigned readings -2.02
e. Seminars 1.94
f. Classroom discussions -1.86
g. Teaching classes -1.84

The question "How stressful have different aspects of graduate student life been for you?" was answered on a scale from 4 (very stressful) to 1 (not stressful). The responses are as follows:
a. Coursework -2.94
b.Maintaining a meaningful life outside of grad. school -2.39
c. Financial situation -2.27
d. Conflict between course contents and your interest -2.25 
e. Doing mathematics -2.22

f. Finding a dissertation topic -2.13

g. Relations with faculty -1.72

h. Relations with students -1.40

\section{Most Respected Economists}

The request to write in the names of the three most respected economists, dead or alive, resulted in the following list of names with the number indicating the frequency with which the name was given:

Keynes 58, Marx 21, Samuelson 20, Smith 17, Friedman 17, Lucas 13, Galbraith 11, Marshall 8, Stiglitz 6, Schumpeter 6, Ricardo 6, Solow 4, Baumol 4, Stigler 4, Steven Cheung 4, Coase 4; 3 each: A. K. Sen, Hicks, Tobin, Arrow, Demsetz, Pigou, Buchanan, Gerald Helleiner, Hayek, Joan Robinson, Debreu, Myrdal; 2 each: Dornbusch, Sargent, Okun, Barro, Patinkin, Lionel Mackenzie, W.W. Rostow, Walras, Alchian, Becker, Boulding, Heilbronner. 6

\section{Political Leanings and Changes}

The request to indicate political leanings was not met by 15 percent of the students. They tended to accompany their act with such comments as 'do not understand the labels' 7 , 'depends on the issue' and 'don't know any more'. One student ticked the entry 'communist'. Three students indicated that they were leaning towards the politics of the 'Green Party and similar organizations concerned with the environment'. Most of the responses went to the following categories where the percentages add to 100 by the inclusion of the entries noted in the preceding paragraphs:

Socialist 13, Social Democrat 18, Liberal 22

Neo-Conservative 12, Conservative 13, Libertarian 8.

A summary representation of these findings indicates that 63 percent were liberal or to the left and 33 percent were to the right of liberal.

A separate question concerned students' movement on political leanings since entering graduate school. There has been movement to the left for 12 percent, to the right for 21 percent and no change for 67 percent. This result confirms Stigler's (1982) suggestion that graduate studies in economics tend to make people more conservative.

\section{Satisfaction with Studies}

The question "Knowing what you know now, would you start graduate school again?" elicited 'Yes, definitely' from 52 percent; "Probably yes" from 35 
percent; 'Probably No' from 8 percent; 'Definitely No' from 3 percent; and 'No, but ask me again tomorrow' from 3 percent.

\section{Evaluation}

Whether or not one finds the demographic information interesting and worthy of comment depends on one's priors. The author found no particular surprise in the age, sex and foreign student composition of the sample and the proportion of students with long-term relationships, children and work-experience. Noteworthy, however, is the relative importance of students from China and other Asian countries, who make up about two-thirds of the foreign students who responded to the survey.

The data on the students' family backgrounds add evidence in support of the view that higher education accrues predominantly to families with high incomes and high levels of education. This is especially so given the fact that 80 percent of the students have their studies financed predominantly through scholarships and research and teaching assistantships. Very surprising is the almost identical educational attainment of the fathers of Canadian and foreign students, where the latter include a large number from China.

The distribution of students according to their intended terminal degree reflects roughly that found at Simon Fraser University and possibly at other graduate departments. There appears to be somewhat of a bias in favour of responses by students during the first two years of their studies. This is unfortunate and should be kept in mind in the interpretation of some of the views discussed below. Given the nature of graduate studies in economics it should not come as a surprise that only about 29 percent of the respondents expect to use their degrees in private sector employment, even in the light of the fact that about half of these degrees are expected to be M.A.'s.

The decision to undertake graduate study in economics was influenced most heavily by personal preferences and abilities. The desire to become involved in policy formation ranked highly, though political considerations and distinct career objectives in academia carried relatively little weight. The choice of thesis topics was influenced most heavily by factors that may be described as idealistic rather than practical, as is evidenced by the relatively low weight given to the suggestions of teachers and the application of mathematical and econometric techniques. Somewhat surprising was the relatively small importance which students attached to teaching classes, classroom discussions and seminars as vehicles of learning.

It is interesting to have a record of the political leanings of Canadian graduate students in economics. Some readers may be surprised by the relative 
size of the group with strong preferences for the ideology of the left, especially since these students have developed their attitudes during the period when conservative economic policies were adopted in many countries, including the Soviet Union and China. It is not clear whether these political leanings reflect simply the students' age and the normal idealism accompanying it or whether they have been and are influenced by their teachers and readings. The former interpretation is supported by the finding that 21 percent of the students have moved to the right and only 12 percent to the left since they entered graduate school.

On the other hand, the ranking of Keynes, Marx and Galbraith (and perhaps even Samuelson) as the most respected economists relative to the ranking of conservatives like Friedman, Lucas and Schumpeter, indicates the influence which these leftist economists have had on the thinking of the students. Presumably, these preferences were influenced heavily by the readings and lectures of their teachers at the undergraduate and graduate levels. Many of those, especially in social sciences other than economics, have been staunch defenders of the leftist ideologies during the years when electorates and politicians in many countries have shifted their alliances.

Given the stresses associated with graduate school, it should please those responsible for the design and management of the graduate programs in Canada that only 11 percent of the students would not again choose their program of study.

The demographic characteristics and views on schooling of the individuals studied here are very similar to those surveyed by Colander and Klamer. The major difference lies in the proportion of M.A. and Ph.D. students. In the sample analyzed by Colander and Klamer were only students at the major U.S. universities: Chicago, M.I.T., Harvard, Stanford, Columbia and Yale. The graduate programs at these institutions are almost exclusively aimed at the graduation of Ph.D.'s. Furthermore, these universities have considerably higher admissions standards than most other U.S. and Canadian universities with graduate programs in economics. This fact should be remembered in the analysis of differences in views on economic propositions and methodology presented in the next section.

\section{The Socialization of Students}

In their study of the economics profession, Grubel and Boland (1986) and Kuttner (1985) discovered a widespread concern with the growth of mathematics in the curriculum of graduate students and the production of 
knowledge. At the risk of oversimplification, it might be suggested that this concern arises from the perception of two undesirable developments which accompany these trends towards mathematics and rigour. First, it will make economics increasingly irrelevant to the understanding of real world problems. Second, access to the profession will become increasingly more difficult and success in it a function of conformity to its sociological norms rather than the production of economic knowledge relevant to the real world.

The following questions were designed to discover the extent to which the views of graduate students reflect the drift to mathematics and the elitism of the profession. Table 3 presents answers to the question: "How important to your development as an economist would you, if you had the time and option, consider readings in or discussions about topics in the following fields?" Answers were 4: very important; 3 : important; 2 moderately important; 1 unimportant. The responses of U.S. graduate students to the same questions as reported by Colander and Klamer are given also.

Table 3

The Importance of Reading in Other Fields

\begin{tabular}{lcc}
\hline \multicolumn{1}{c}{ Field } & Canadian Students & U.S. Students \\
Mathematics & 3.08 & 3.08 \\
Political Science & 2.77 & 2.65 \\
Humanities & 2.65 & N.A. \\
Computer Science & 2.55 & 2.12 \\
History & 2.55 & 2.94 \\
Philosophy & 2.47 & 2.50 \\
Sociology & 2.23 & 2.40 \\
Psychology & 2.11 & 2.11 \\
Languages & 2.05 & N.A. \\
Physics & 1.47 & 1.45 \\
\hline
\end{tabular}

Table 4 presents answers to the question "How important do you consider the following characteristics for students and academics who wish to get ahead quickly in the economics profession?" The scale of answers was the same as in the preceding question except for 1: 'don't know'. In the calculation of the index the 'don't know' answers were omitted. 
Table 4

Perceptions of Success

\begin{tabular}{|c|c|c|}
\hline Question & \multicolumn{2}{|c|}{ Students } \\
\hline 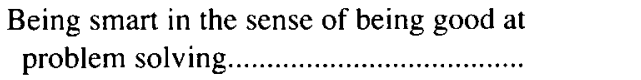 & 3.53 & 3.63 \\
\hline Excellence in mathematics and model building..... & 3.42 & 3.55 \\
\hline Being interested in, and good at, empirical & 3.19 & 2.98 \\
\hline 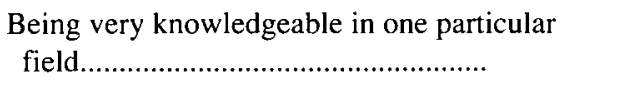 & 3.14 & 3.18 \\
\hline Ability to make connections with prominent & & \\
\hline 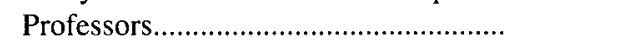 & 3.02 & 3.14 \\
\hline A broad knowledge of the economics literature.... & 3.00 & 2.62 \\
\hline $\begin{array}{l}\text { Thorough knowledge of the economy and its } \\
\text { history }\end{array}$ & 2.73 & 2.30 \\
\hline
\end{tabular}

\section{Evaluation}

The perceived importance of readings in other fields reflects the role played by mathematics and computer science in the profession. On the other hand, the importance attached to readings in other social sciences and humanities suggests that most students are aware of the extent to which knowledge in these fields is necessary to be a good economist. It is worth mentioning here that Colander and Klamer in personal interviews of students discovered that few had the time to read anything in other fields, in spite of their expressions of the desirability to do so. Presumably, the same is true for Canadian students and the data should be interpreted in the light of this possibility. The comparison of the responses of Canadian and U.S. students shows a surprising correspondence in the ratings for mathematics, physics and most of the social sciences. Canadians attached more importance to readings in political and computer science than did their U.S. colleagues. The opposite was true for history.

The data in Table 4 are most relevant to the assessment of the extent to which graduate student attitudes reflect the trend towards mathematization and modelbuilding in the profession. Students believe that advancement is aided much more by skills in these fields than it is by broad, historic knowledge of the economy. Even the benefits from specialization and skills in empirical work are considered much less important than the skills of problem-solving, mathematics and model-building. A comparison of Canadian and U.S. students shows that the latter consider empirical and broad knowledge to be even less important than do the former. 


\section{Opinions on Key Propositions in Economics}

Frey and his colleagues (1984) surveyed U.S. economists on a set of key economic propositions. ${ }^{8}$ The results were considered to be of sufficient scientific interest that the paper was acceptable to the editors of the American Economic Review. It also stimulated others to ask the same questions of different populations of economists, Colander and Klamer (1987) and Block and Walker (1988), who surveyed U.S. graduate students and Canadian professional economists, respectively. In Table 5 the results of the survey of Canadian graduate students is shown along with those from the other populations. In all surveys there were minor differences in the wording of some questions. Answers were given in the classes: 4 agree; 3 agree with some reservations; 2 disagree; 1 no view. The index in this and all of the following tables was calculated by multiplying the number of responses in each category by the values of 4 to 2 , respectively and division by the total number of responses in these classes. ${ }^{9}$

Canadian graduate students are strongly convinced that protection reduces general economic welfare, that fiscal policy is an effective stabilization tool and that inflation is primarily a monetary phenomenon. They are somewhat less convinced that minimum wages cause unemployment and that central banks should behave in a monetarist fashion. They disagree quite strongly with the ideas that wage and price controls should be used to control inflation and that the capitalist system is crisis prone.

Kendall's rank correlation coefficients for the first six propositions and concerning the 4 groups were as follows. For Canadian graduate students and Canadian professionals, the coefficient is .67 , which is about the same as that between U.S. graduate students and professionals. The correlation in the rankings is highest between the graduate students of the two countries and lowest between Canadian students and U.S. professionals. At a less formal level, the following matrix provides some useful insights about agreement among the four groups.

Proposition

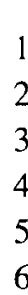

Rank for Groups

$\begin{array}{llll}\text { A } & \text { B } & \text { C } & \text { D } \\ 2 & 3 & 2 & 2 \\ 5 & 5 & 5 & 5 \\ 4 & 2 & 3 & 1 \\ 1 & 1 & 1 & 3 \\ 3 & 4 & 4 & 4 \\ 6 & 6 & 6 & 6\end{array}$


Table 5

\section{Views on Key Propositions}

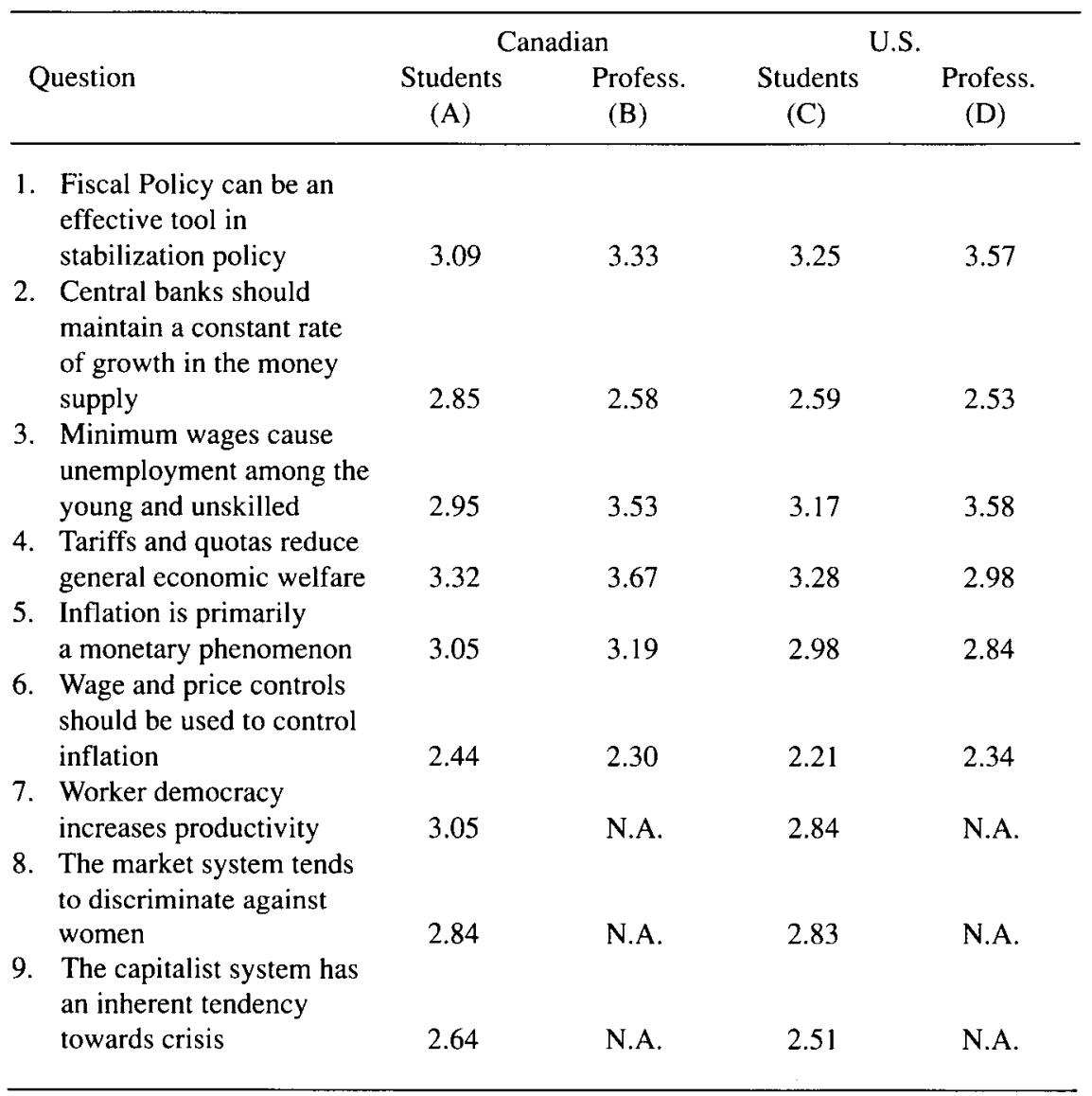

All four groups are unanimous in their answers to propositions 2 (monetarism for central banks) and 6 (the merit of controls). Canadian students are on the side of the majority of groups with respect to proposition 1 (the merit of fiscal policies) and 4 (the cost of protection). They are in the distinct minority on question 5 (the monetary explanation of inflation).

\section{Views by Universities of Enrolment}

One interesting aspect of differences in views on some key economic propositions concerns the influence of schools of thought and academic 
traditions. In the study of U.S. students the views on propositions were broken down by the universities at which they were enrolled. Large differences emerged between Chicago, M.I.T.,Harvard, Stanford and Columbia, especially with respect to the merits of fiscal policy and monetarist propositions. In Table 6 the views of Canadian students on these questions are shown for 10 universities from which at least 6 completed surveys had been received. ${ }^{10}$

It can be seen that there are substantial differences in the levels of the index across the universities listed. Dalhousie, Calgary and Queen's students believe most strongly in the efficacy of fiscal policies. Students at the other end of the spectrum on this question are at Saskatchewan, Toronto, Carleton and Simon Fraser University. Monetarism as evidenced by the indices on questions 2 and 5 has its greatest following at Simon Fraser University and somewhat less so at Toronto and Saskatchewan. There appears to be some correlation between the strength of belief in fiscal policy and the lack of belief in the monetarist propositions.

Simon Fraser University students again have the highest degree of conviction that minimum wages raise unemployment while Dalhousie and Queen's students least believe in the validity of this proposition. The highest index of agreement and consensus among students in all universities is found on the harmful effects of protection. The efficacy of wage and price controls and the leftist proposition about the capitalist crisis receive universally low support. A wide dispersion of views is found on the market's discrimination against women, with Dalhousie, University of British Columbia and Victoria students supporting the assertion the most and those at Toronto, Carleton and Simon Fraser University the least.

\section{Evaluation}

The data in Table 5 suggest that the views of Canadian graduate students on some basic propositions in economics are very similar to those of professionals in Canada and the two U.S. groups. Consensus among the groups as measured by rankings extends over both some price-theoretic and Keynesian-Monetarist propositions in macro-economics. This is in contrast with the findings by Block and Walker that consensus among economists is highest on matters concerning micro-economic phenomena, less so on macro-economic issues and least on policy problems that involve income redistribution. ${ }^{11}$ Most puzzling is the fact that the correlation of the rankings is highest among the students of the two countries. One possible explanation of this phenomenon is that the students reflect the views of their teachers, almost all of whom have a Ph.D. and pass on 
Table 6

Comparison Among Canadian Universities

\begin{tabular}{|c|c|c|c|c|c|c|}
\hline \multicolumn{2}{|c|}{ University: } & Dalhousie & Carleton & Toronto & Queen's & U.B.C. \\
\hline \multicolumn{2}{|c|}{ Numb. Observ. } & 16 & 9 & 6 & 19 & 9 \\
\hline \multicolumn{7}{|c|}{ Question } \\
\hline 1 & Fiscal Policy & 3.50 & 2.89 & 2.83 & 3.17 & 3.00 \\
\hline 2 & Money Supply & 2.91 & 2.78 & 2.50 & 3.00 & 2.44 \\
\hline 3 & Min. Wages & 2.53 & 3.11 & 3.00 & 2.56 & 3.00 \\
\hline 4 & Protection & 3.00 & 3.56 & 3.60 & 3.22 & 3.22 \\
\hline 5 & Inflation & 2.69 & 3.00 & 3.33 & 2.72 & 2.89 \\
\hline 6 & Controls & 2.43 & 2.00 & 2.33 & 2.28 & 2.00 \\
\hline 7 & Worker Demo & 3.23 & 3.00 & 3.17 & 2.92 & 3.00 \\
\hline 8 & Women Discr & 3.22 & 2.43 & 2.33 & 2.78 & 3.14 \\
\hline 9 & Capit. Crisis & 2.50 & 2.38 & 2.33 & 2.60 & 2.43 \\
\hline \multicolumn{2}{|c|}{ University: } & S.F.U & Victoria & WestOnt. & Calgary & Sask. \\
\hline \multicolumn{2}{|c|}{ Numb. Observ. } & 26 & 20 & 10 & 8 & 8 \\
\hline \multicolumn{7}{|c|}{ Question } \\
\hline 1 & Fiscal Policy & 2.92 & 3.05 & 3.00 & 3.25 & 2.57 \\
\hline 2 & Money Supply & 3.09 & 2.71 & 2.63 & 2.63 & 3.00 \\
\hline 3 & Min. Wages & 3.15 & 3.14 & 3.00 & 2.88 & 3.00 \\
\hline 4 & Protection & 3.38 & 3.23 & 3.44 & 3.25 & 3.25 \\
\hline 5 & Inflation & 3.48 & 3.20 & 2.80 & 2.50 & 3.29 \\
\hline 6 & Controls & 2.17 & 2.35 & 2.45 & 2.13 & 2.63 \\
\hline 7 & Worker Demo & 3.00 & 3.13 & 3.00 & 2.50 & 2.86 \\
\hline 8 & Women Discr & 2.68 & 3.12 & 2.71 & 3.00 & 2.88 \\
\hline 9 & Capit. Crisis & 2.63 & 2.68 & 2.67 & 2.88 & 2.71 \\
\hline
\end{tabular}

the latest knowledge in both countries. 12 The broader populations of economists contain many with qualifications lower than the Ph.D. and possibly holding views acquired many years ago.

The main conclusion emerging from a study of Table 6 is that there is relatively great consensus among Canadian graduate students at different universities with respect to propositions that involve price-theoretic principles, such as the effects of protection and wage and price controls. At the other extreme, there is a wide dispersion of views on propositions from macro and monetary economics. Undoubtedly, schools of thought have developed and the views of students are influenced heavily by the culture and work of professors in their respective institutions. In this respect, Canadian and U.S. universities are very similar.It can be seen from Table 6 on the issues of macro-economics, 
the opinions of Simon Fraser University students are the most distinctly different from those held by students at other Canadian universities. In comparison with the results reported by Colander and Klamer, the Simon Fraser University students' views resemble most those of Chicago students .

\section{Issues of Methodology}

Differences in the views of economists in the longer run are influenced partly by the theoretical, empirical and institutional knowledge they acquired in graduate school. However, more important may well be the methodological principles that they have learned. These tend to influence their approach to the study and interpretation of the constantly changing environment and new knowledge for at least some time after completion of their studies. For this reason, Colander and Klamer and the survey of Canadian students have asked for views on some fundamental issues of methodology. Because Colander and Klamer found large differences in students' answers from different universities, the summary index of those and of students from Canadian universities are presented in Table 7.13

The first proposition, which concerns the relevance of neoclassical economics, most differentiates the attitudes of students at Chicago and the other U.S. universities, but especially M.I.T. and Harvard. An interesting approach to the analysis of Canadian views is to see into which of the three U.S. camps they fall. Canadian students on average clearly believe much less in the validity of the proposition than do the U.S. students on average. In fact, the overall index for Canada is about the same as that for Harvard, which is the second lowest of the U.S. universities. Toronto students have the second highest index on the list, following Chicago's. Simon Fraser University is second in Canada but is lower than that of Stanford and Yale and equal to that of Columbia. The students at Carleton, Dalhousie, Western Ontario, Queen's and University of British Columbia share a skepticism that resembles that held by students at M.I.T. and Harvard. The proposition concerning the scientific nature of economics also shows a great variance among universities in both countries and shows Chicago students with the strongest confidence in the validity of the proposition. The Canadian universities Victoria, Calgary and Saskatchewan are closest to Chicago. Simon Fraser University students, after those from Dalhousie, have the least confidence in the scientific nature of economics.

A look at the range of values for all Canadian and U.S. respondents shows an interesting difference. The range of values is only .54 for the Canadian and 1.23 for the U.S. responses. This may be interpreted as indicating that U.S. students 
tend to have stronger and more "extreme" views on the issues surveyed or that there is a wider range of scholarly-ideological traditions.

Table 7

Views on Methodology

\begin{tabular}{lcccc}
\hline Universities & \multicolumn{4}{c}{ Questions (For formulation see at bottom) } \\
& 1 & 2 & 3 & 4 \\
Dalhousie & 2.79 & 2.33 & & \\
Carleton & 2.63 & 2.75 & 2.47 & 2.56 \\
Toronto & 3.40 & 2.00 & 2.71 & 2.89 \\
Queen's & 2.89 & 2.53 & 2.80 & 2.80 \\
University of & 2.89 & 2.43 & 2.60 & 2.82 \\
British Columbia & & & 2.00 & 2.63 \\
Simon Fraser & 3.17 & 2.63 & & \\
$\quad$ University & & & 2.68 & 2.71 \\
Victoria & 3.00 & 2.59 & & \\
Western Ontario & 2.88 & 2.56 & 2.31 & 3.35 \\
Calgary & 3.13 & 2.05 & 2.33 & 2.71 \\
Saskatchewan & 3.14 & 3.14 & 2.38 & 3.33 \\
$\quad$ All Canadian & 2.97 & 2.47 & 2.00 & 3.29 \\
& & & 2.43 & 2.90 \\
Chicago & 3.66 & 2.56 & & \\
M.I.T. & 2.39 & 2.39 & 2.87 & 3.45 \\
Harvard & 2.98 & 2.30 & 2.31 & 3.03 \\
Stanford & 3.28 & 2.57 & 2.20 & 2.74 \\
Columbia & 3.16 & 2.58 & 2.51 & 3.05 \\
Yale & 3.28 & 2.63 & 2.38 & 3.09 \\
$\quad$ All U.S. & 3.23 & 2.00 & 2.47 & 2.73 \\
& & & 2.43 & 3.10
\end{tabular}

Questions:

1. The study of neoclassical economics is relevant for the economic problems of today

2. Economists agree on fundamental issues

3. There is a sharp line between positive and normative economics

4. Economics is the most scientific social science

Scoring Categories - 4: strongly agree; 3 : agree somewhat; 2 : disagree; 1 : no opinion. The index is the weighted average of responses in the first three categories.

Note: The index for all Canadian universities includes those in the table and all those for which the number of responses was too small to warrant calculation of a separate index. The U.S. index is based on the sample of universities shown only. 


\section{Views on Mathematics}

Mathematical skills are acquired at the expense of skills in other fields. The extent to which students are willing to sacrifice the learning of one at the expense of the other depends on the views they hold about their usefulness. These views are probed with the questions reviewed in Table 8. Differences among universities and schools of thought are of some interest and therefore are shown in Table 8.

One of the outstanding characteristics of the natural sciences is that knowledge is cumulative. In all Canadian universities surveyed students believed strongly that economics in this sense is a science. It appears that this view is held widely among economists, though the rise and fall of economic doctrines, such as the quantity theory of money, Keynesianism and purchasing power parity has led some to question its validity.

Some methodologists argue that mathematical models are sophisticated tautologies since all conclusions follow strictly from the assumptions made. Since assumptions can be chosen from a very large set and since all must of necessity involve a drastic simplification of the real world, such models can be designed to prove almost anything and their usefulness for the guidance of policy is strictly limited. ${ }^{14}$ Students at Canadian universities on average are split on their acceptance of these propositions. Those at Carleton, Victoria, Calgary and British Columbia showed the strongest faith in the usefulness of mathematical models for policy, those at Toronto and Simon Fraser University the least.

The proposition that mathematical modelling is useful for the understanding of economics is accepted more strongly than that about the use of the methodology for the guidance of policy. The views on this matter differ widely among universities. The validity is accepted most strongly at Victoria and Queen's and least at Simon Fraser and Dalhousie.

The question concerning the realism of assumptions is closely related to the issue of mathematical model-building. Friedman argues that the usefulness of all models is determined by the empirical support that can be found for them, especially their ability to predict relationships between variables. On average, Canadian graduate students disagree with the validity of this methodological proposition. Students at the University of British Columbia are the most consistent in the strength with which they support the usefulness of mathematical models and insist on the realism of assumptions. It would seem that the economics profession is split on the validity of the proposition that econometrics can be used to support any desired hypothesis. On the one hand, it 
is widely recognized that with the low cost of computing services and an abundance of data, there is a lot of data-mining and simultaneous model building. On the other hand, there is much econometric work which draws on sound models and classical testing and measurement. The problem for the reader of econometric studies is to know reliably which methodology was used by the author. Graduate students at Canadian universities reflect this problem and the division in the profession at large. At Toronto and Saskatchewan they are the most cynical about the use of econometrics, they are least so at Queen's, by a large margin over the rest.

Table 8

Mathematics, Econometrics, History and Institutions

\begin{tabular}{lccccccccc}
\hline Universities & \multicolumn{8}{c}{ Questions (For formulation see at bottom) } \\
& 1 & 2 & 3 & 4 & 5 & 6 & 7 & 8 \\
& & & & & & & & \\
Dalhousie & 3.7 & 2.6 & 2.7 & 2.3 & 3.6 & 3.6 & 2.1 & 2.9 \\
Carleton & 3.7 & 3.0 & 2.8 & 2.4 & 2.8 & 3.3 & 2.4 & 3.0 \\
Toronto & 2.8 & 2.2 & 3.0 & 2.6 & 4.0 & 4.0 & 2.0 & 3.0 \\
Queen's & 3.2 & 2.7 & 2.4 & 2.4 & 2.7 & 3.3 & 2.4 & 3.3 \\
U.B.C. & 3.3 & 2.9 & 2.6 & 2.1 & 3.3 & 3.4 & 2.0 & 3.0 \\
S.F.U. & 3.4 & 2.6 & 2.8 & 2.8 & 3.5 & 3.5 & 2.3 & 2.8 \\
Victoria & 3.5 & 3.0 & 2.7 & 2.4 & 3.0 & 3.1 & 2.2 & 3.5 \\
Western & 3.3 & 2.7 & 2.8 & 2.3 & 3.5 & 3.3 & 2.2 & 2.8 \\
$\quad$ Ontario & & & & & & & & \\
Calgary & 3.1 & 3.0 & 2.8 & 3.0 & 3.0 & 3.1 & 2.8 & 3.1 \\
Saskatchewan & 3.8 & 2.8 & 3.0 & 2.9 & 2.7 & 3.5 & 2.0 & 3.1 \\
All Universities & 3.4 & 2.7 & 2.8 & 2.4 & 3.2 & 3.4 & 2.2 & 3.0
\end{tabular}

Questions:

1. Economics knowledge is cumulative

2. Mathematical models reflect the real world and therefore can help guide policy

3. Econometrics can be used to support any desired hypothesis

4. The realism of assumptions is irrelevant for the value of models

5. The study of economic history and institutions is necessary to become an effective economist

6. There is no such thing as a value-free model in economics

7. The history of thought is irrelevant for today's students of economics

8. Mathematical modelling is essential for understanding economics

Answers:

4: strongly agree; 3 : agree with reservations; 2 : disagree; 1 : no views.

The index omits answers in category 'no views'. 
Canadian graduate students are quite strongly in support of the view that the study of history, institutions and economic doctrines are important for economists. This is consistent with a belief in the usefulness of rigorous mathematical modelling since, presumably, such broader historic and institutional studies encourage the choice of appropriate assumptions. There is a problem associated with these views, as has been pointed out elsewhere (Grubel and Boland (1986)). The study of mathematics and modelling competes for time with the study of history, doctrine and other less rigorous fields. During the postwar years the former have won out over the latter to a degree which is disturbing to some; the situation has elicited such extreme statements as the one about the graduation of idiots savants quoted above. In a sense it is reassuring to know that students value the historic, institutional and doctrinal studies and that the problem may lie with supply rather than demand.

\section{Summary and Conclusions}

The survey of Canadian graduate students in 1988 provides some interesting demographic data concerning their age, sex, nationality, parental background, professional aspirations and financing, which may well serve as an historic benchmark for the assessment of trends in the future. Perhaps most interesting is the parental background, which supports the view that graduate studies in economics attracts the children of highly educated families with high incomes. On the other hand, the results also show that through the availability of scholarships and work as teaching assistants, the system permits the enrolment of many from families with low income and educational attainment.

The political leanings of graduate students are distinctly to the left. However, in the course of their studies, more have turned right than left.

The survey of views on fundamental propositions in economics showed a widespread agreement with the views held by Canadian and U.S. professionals and U.S. graduate students. Perhaps most interesting is the finding that the views of Canadian graduate students correlate most strongly with those of U.S. graduate students. Another interesting result of the study of views on basic propositions concerns responses classified by universities of enrolment. There is widespread agreement on price-theoretic propositions. The dispersion of views is widest on issues of macro-economic policies and income distribution.

Students in Canadian graduate schools believe strongly in the importance of technical and particularly mathematical skills for getting ahead in the profession. Empirical and historical knowledge are the least important in this sense. At the same time, they strongly support the view that such empirical and 
historical knowledge is important for becoming an effective economist. Interest in getting involved in policy formulation has been an important influence on their entry into graduate studies in economics.

Perhaps this conflict between technical and other knowledge is the most important finding of this survey. It agrees roughly with that done by Colander and Klamer (1988) and the analysis of Grubel and Boland (1986). The need to get established in an increasingly technical discipline has forced students to accept its norms. This acceptance has taken place in spite of the students' conviction about the importance of less technical knowledge and the risk that the discipline is becoming irrelevant for policy and current problems.

\section{Footnotes}

1 Twenty-six responses were received from students at Simon Fraser University, where 75 in residence received the questionnaire. The number of responses, size of the student population who received the questionnaire, names of universities and professors who handled the chores are as follows: 20/26 responses from the University of Victoria; 19/103 from Queen's University, Douglas Purvis; 16/35 from Dalhousie University, Paul Huber; 10/60 from the University of Western Ontario, John Palmer; 9/35 from Carleton University, Steven Ferris; $8 / 72$ from the University of British Columbia, Sam Ho; 8/37 from the University of Calgary, Malcolm Brown; 8/35 from the University of Saskatchewan, Isabel Anderson; 6/50 from the University of Toronto, Edward Safarian; $5 /$ ? from Concordia University, Philippe Callier; $5 / 12$ from the University of Waterloo, Wayne Thirsk; 4/? from McGill University, John McCallum; 4/12 from Laval University, Roger Dehem; 4/35 from McMaster University, William Scarth; 4/22 from the University of Guelph, John Vandercamp. Paul Booth at the University of Alberta, Rodrigue Tremblay at the University of Montreal, Michel Bergeron at the University of Quebec at Montreal, Norman Cameron at the University of Manitoba, Don McCharles at the University of New Brunswick, and Ronald Bodkin at the University of Ottawa were mailed questionnaires but for a variety of reasons did not generate any responses. Many thanks to those colleagues who cooperated in this venture and to the students who took the time to complete the questionnaire.

2 It can be seen from the preceding footnote that in the case of two universities the size of the student population could not be ascertained. These were omitted from the calculation of the response rate. It may also be worth noting how the students were approached. In the case of the University of Calgary, University of British Columbia and Carleton University, the survey went to all registered students. In all other cases the survey was distributed to students on campus through mail-boxes in the department.

3 Three otherwise useful questionnaires did not have demographic information. In the remainder of this paper the number or percentage of incomplete answers is not noted, except where this information is important. 
4 Many students indicated preferences for several of the categories. Each of the preference was recorded without any weight given to rankings. Two students expressed an interest in working for international organizations.

5 Some information is lost by not providing the reader with a complete distribution of answers in each category. However, the saving of space and reduced risk of informational overload influenced the decision to use only the summary index. As it turns out, the ranking of answers by the index and the number of answers in 'very important' is almost perfectly correlated. For these reasons, all of the results below are presented also in the form of a summary index.

It should be noted that the index used here does not give an indication of the dispersion of answers or degree of consensus. For example, the index has the same value of 2 under two vastly different conditions. Under the first, all answers are in the category 'somewhat important'. Under the second, half of the answers each are in the categories 'very important' and 'unimportant'. The degree of consensus in this sense can be measured by an index of entropy used by Block and Walker (1988). Such an index is not presented here since the degree of consensus is not of any particular analytical interest. Furthermore, a casual inspection of the responses suggests the almost total absence of bimodality in the answers.

6 First names were omitted except in cases where it was felt identification was facilitated. The names of individuals mentioned only once are Akerloff, Amott, Baron, Bator, Bauer, Bhagwati, Blaug, Blinder, Carnoy, Fidel Castro, Diamond, Dockner, H. Scott Gordon, Heckscher, Hotelling, Jevon, Ron Jones, Alfred Kahn, Knight, Elisabeth Landes, Leontieff, Arthur Lewis, Richard Lipsey, Little, Malinvaud, Gerald Meier, Richard Merton, von Mises, J.S. Mill, Mundell, R.R. Nelson, T.W.Schultz, Schumacher, Shackle, Herbert Simon, Lawrence Summer, Thurow, Von Neuman, O. Williamson, J.R. Winter. Not listed are 4 individuals (including the author) who were obviously current or recent teachers of the students who completed the survey. Two of the three references to Helleiner came from students at the University of Toronto.

7 This may have been a difficulty for some others, especially with respect to the term 'libertarian'. Two students who identified themselves as libertarians at the same time noted in a subsequent response that they 'moved to the right' since they entered graduate school.

8 They also surveyed economists from European nations. To keep the analysis manageable, these findings are not discussed here.

9 The indices for the survey results of other authors were calculated in the same manner from the data published in the original sources.

10 It should also be noted that in the calculation of the index, responses of 'No view' were excluded. In the case of some questions with already small number of observations, the index is therefore based on very few observations. 
11 It should be noted that the Block-Walker conclusions are based on a larger set of questions and the use of an index of entropy. This index reflects the degree of dispersion of answers in the classes of response.

12 Block and Walker found significantly different answers on a large number of issues given by Canadian economists with and without a Ph.D.

13 Canadian students were also asked to indicate their views on these methodological issues before they entered graduate school and currently. The data in Table 7 are current views. The following are the indices for the four issues held currently and before, respectively. $1: 2.97$ from $2.94 ; 2: 2.47$ from $2.59 ; 3: 2.43$ from $2.67 ; 4: 2.90$ from 2.99. On each question, about half of the respondents did not change their views.

14 These views on methodology are not anti-theoretical. To the contrary, methodologists from this tradition typically argue that theory is needed to guide empirical work. The main point at issue is that mathematical models without empirical support are not reliable guides for policy.

\section{References}

Block, Walter, \& Walker, Michael. (1988). Entropy in the Canadian economics profession: Sampling consensus on the major issues. Canadian Public Policy, 14 (2), June.

Colander, David, \& Klamer, Arjo. (1987). The making of an economist. Economic Perspectives, I (2), Fall.

Frey, Bruno S., Pommerehne, Werner W., Schneider, Friedrich, \& Gilbert, Guy. (1984). Consensus and dissension among economists: An empirical inquiry. American Economic Review, 74 (5), December.

Grubel, Herbert \& Boland, Lawrence. (1986). On the efficient use of mathematics in economics: Some theory, facts and results of an opinion survey. Kyklos, 3.

Kuttner, Robert. (1985). The poverty of economics. The Atlantic Monthly, February.

McCloskey, Donald. (1986). The Rhetoric of Economics. Madison: University of Wisconsin Press.

Stigler, George. (1982). The Economist as Preacher. Chicago: Chicago University Press. Ward, Benjamin. (1972). What's Wrong with Economics. New York: Basic Books. 